\title{
Effect of Coconut Peat on the Growth and Yield Response of Ipomoea aquatica
}

\author{
Md. Zulfikar Khan*, Monia Dislhad Era, Md. Ariful Islam, Rikta Khatun, Afroza Begum, \\ Shaikh Motasim Billah
}

Soil, Water and Environment Discipline, Khulna University, Khulna, Bangladesh

Email: ${ }^{\star Z u l f i k a r . k u 11 @ g m a i l . c o m ~}$

How to cite this paper: Khan, Md.Z., Era, M.D., Islam, Md.A., Khatun, R., Begum, A. and Billah, S.M. (2019) Effect of Coconut Peat on the Growth and Yield Response of Ipomoea aquatica. American Journal of Plant Sciences, 10, 369-381.

https://doi.org/10.4236/ajps.2019.103027

Received: October 28, 2018

Accepted: March 8, 2019

Published: March 11, 2019

Copyright $\odot 2019$ by author(s) and Scientific Research Publishing Inc. This work is licensed under the Creative Commons Attribution International License (CC BY 4.0).

http://creativecommons.org/licenses/by/4.0/

\begin{abstract}
A pot experiment was conducted to investigate the effect of coconut peat on growth and yield response of Ipomoea aquatica for Pirojpur soil series during the period of $24^{\text {th }}$ May to $25^{\text {th }}$ June, 2017. The experiment was laid to fit a completely randomized design (CRD) with five treatments [control $\left(\mathrm{T}_{0}\right), 1000$ $\mathrm{kg}$ coconut peat ha ${ }^{-1}\left(\mathrm{~T}_{1}\right), 1500 \mathrm{~kg}$ coconut peat $\mathrm{ha}^{-1}\left(\mathrm{~T}_{2}\right), 2000 \mathrm{~kg}$ coconut peat $\mathrm{ha}^{-1}\left(\mathrm{~T}_{3}\right)$ and $2500 \mathrm{~kg}$ coconut peat $\left.\mathrm{ha}^{-1}\left(\mathrm{~T}_{4}\right)\right]$ each having three replications for this experiment. After plant harvesting, the laboratory investigation was carried out in the Soil, Water and Environment Discipline, Khulna University, Khulna, Bangladesh. Yield contributing characters like number of leaves, fresh weight and dry weight were significantly $(\mathrm{P}<0.05)$ influenced by different treatments. By contrast root length and shoot length were insignificantly varied compared to control $\left(\mathrm{T}_{0}\right)$ treatment but from the eye observation and analytical data confirm increasing trend for the application of coconut peat. Among the five treatments applied $\mathrm{T}_{4}$ treatment $(2500 \mathrm{~kg}$ coconut peat $\mathrm{ha}^{-1}$ ) has shown highest response to plant growth due to nutrient availability of the soil. The sequence of response was in the order $\mathrm{T}_{4}>\mathrm{T}_{3}>\mathrm{T}_{2}>$ $\mathrm{T}_{1}>\mathrm{T}_{0}$ and significantly $(\mathrm{P}<0.05)$ difference in plant growth from the control $\left(\mathrm{T}_{0}\right)$.
\end{abstract}

\section{Keywords}

Effects, Coconut Peat, Growth, Yield Response, Moisture Content, Ipomoea aquatic

\section{Introduction}

In recent years, intensive crop cultivation using high yielding varieties of crop with imbalanced fertilization has led to mining out scarce native soil nutrients to 
support plant growth and production, the dominant soil ecological processes that severely affected the fertility status and production capacity of the major soil in Bangladesh. Available data indicated that the fertility of most of our soils deteriorated over the years [1]. Organic matter content of most of the Bangladesh soils is very low where the majority fall below (1.5\%) the critical level [2]. The organic matter content of Bangladesh soils in the continuously cropped areas from 1967 to 1995 has been depleted by 5\% to 36\%. The addition of organic materials to soil through FYM, compost and organic residues (coconut peat and crops residue) is used up as fuel by the rural people [3].

Coconut peat is available in large quantities as a by-product of the coconut industry. In the last few years, coir dust has been promoted [4] or considered [5] as a substitute for natural peat in potting media. The particular structure of coconut fibers and their physical and chemical properties, make them suitable for container media purposes [6]. In fact, the use of coconut fiber in European greenhouse production is well accepted as new technology. Coir contains equal portions of lignin and cellulose and is rich in potassium and the micronutrients $\mathrm{Fe}, \mathrm{Mn}, \mathrm{Zn}$, and $\mathrm{Cu}$. Due to the high potassium content of the media a reduction in potassium fertilization has been shown to produce beneficial results [7]. However, some studies have shown that it is necessary to increase the nitrogen fertilization for coir grown plants to compensate for $\mathrm{N}$ immobilization of the media. Coconut peat has allowed Cation Exchange Capacity (21 - 30 meq /L) so it does not retain cations or buffer against $\mathrm{pH}$ change well [8]. Coconut peat has a high-water holding capacity and has been traditionally used to improve the physical and chemical properties of soils [9]. When applied to agricultural soils coconut peat can improve moisture retention capacity, and increase available nutrient content, infiltration rate, total porosity, and hydraulic conductivity of that soil [9] [10].

The increasing world population and its pressure on higher food production through the cultivation of high yielding varieties and its intensification have resulted in a greater demand of fertilizer. Fertilizers are one of the most important inputs of increasing the productivity of crops and modern varieties of different crops [2] [3]. In today's era, heavy doses of chemical fertilizers and pesticides are being used by the farmers to get a better yield of various field crops. The continuous use of inorganic fertilizer will cause damage on physical, chemical and biological properties of soil, so that the soil fertility will more decreased [11]. Chemical fertilizer often has low use efficiency, meaning that only a portion of the applied nutrients are taken up by plants [12]. Although chemical fertilizer increases soil fertility, it is doing more harm than good in that soil itself is being degraded in one hand and the environment is being polluted on the other hand [13].

From the above discussion, it is evident that the application of coconut peat enhances the soil physical, chemical and biological properties as well as plant growth and yield. Coconut peat as organic manure can also help in reducing environmental pollution and increasing the use of organic fertilizer in soil. This 
made me interested to picking up the research. Therefore, the main objective of the present research was to evaluate the effect of coconut peat on the growth and yield response of Ipomoea aquatica.

\section{Materials and Methods}

A pot experiment was conducted in the net house at the premises of the Soil, Water and Environment Discipline, Khulna University, Khulna, Bangladesg during the Kharif season from $24^{\text {th }}$ May to $25^{\text {th }}$ June, 2017 to evaluate the effect of coconut peat on the growth and yield of Ipomoea aquatica. The net house experiment, collection and preparation of soil and plant samples and analytical methods adopted during the course of investigation were presented in this chapter.

\subsection{Description of Reference Soil}

The soil used in the experiment belongs to the "Pirojpur series". Soil samples were collected from the agricultural field behind the Khulna University in Khulna district, Bangladesh. The soil sample was collected from surface $(0-15 \mathrm{~cm})$ on the basis of composite sampling method as suggested by the soil survey staff of the USDA (1951). The location of sampling area was $22^{\circ} 48.302 \mathrm{~N}$ and $89^{\circ} 31.962 \mathrm{E}$. According to Reconnaissance soil survey report [14], the Pirojpur series comprises seasonally shallowly to deeply flooded, poor drained soils, developed in tidal clay deposits. They have dark non-calcareous silty clay to clay subsoil with strong prismatic and blocky structure with dark grey cutans along ped faces overlying buried peat or muck within a depth of 4 feet [15]. This soil could therefore be successfully used to study the changes in the growth and yield of Ipomoea aquatica as influenced by different levels of coconut peat treatments. General information of the experimental soil was shown in Table A1.

\subsection{Soil and Pot Preparation}

The collected soil samples were air dried ground and screened to pass through a $2.0 \mathrm{~mm}$ sieve and then mixed thoroughly to make it a composite sample. Dry roots, grasses and other vegetative residual parts were discarded from the soil. One kg of composite sample was kept in a plastic container for physical and chemical analysis. Three (3) $\mathrm{kg}$ of air-dried composite soil samples were taken in each of the earthen pots and used in this experiment, had no pore in the bottom to protect leaching of coconut peat from the soil. In addition, soil moisture was maintained at field capacity as required and room temperature was maintained in the pots.

\subsection{Collection and Application of Coconut Peat}

Coconut peat was collected from coconut peat production site, Rampal Upazila under Khulna district in Bangladesh. Coconut peat was applied at the different rates such as $1000 \mathrm{~kg}$ coconut peat ha ${ }^{-1}, 1500 \mathrm{~kg}$ coconut peat ha ${ }^{-1}, 2000 \mathrm{~kg}$ co- 
conut peat ha ${ }^{-1}, 2500 \mathrm{~kg}$ coconut peat ha ${ }^{-1}$ and $0 \mathrm{~kg}$ coconut peat ha ${ }^{-1}$ (Control). Coconut peat was applied by broadcasting worked into the experimental pots. In order to provide enough time to decompose the coconut peat, they were applied to the soil before the seed was sowed.

\subsection{Test Crop Used in the Experiment}

The effect of coconut peat in the environment and its impact on the growth and yield of a selected leafy vegetable Water spinach (Ipomoea aquatica) was used as the test crop for the experiment. This particular variety has gained popularity among the farmers of the study area for their high yielding potential and can be grown throughout the year and harvested in a short time within one month [16].

\subsection{Experimental Design and Treatments}

The experiment was laid to fit a completely randomized design (CRD) [17] with five treatments, each having three replications. Three (3) $\mathrm{kg}$ supplied soil sample was used in each earthen pot $(15.5 \mathrm{~cm} \times 9.5 \mathrm{~cm})$ for this experiment.

\subsection{Coconut Peat Treatment}

Four different rates of decomposed coconut peat were used as treatments in the experiment and a control experiment was also conducted. Three replications were conducted for each treatment to avoid experimental error. The treatments are as follows:

$$
\begin{aligned}
& \mathrm{T}_{0}=0 \mathrm{~kg} \text { coconut peat ha } \mathrm{ha}^{-1} \text { (Control), } \\
& \mathrm{T}_{1}=1000 \mathrm{~kg} \text { coconut peat } \mathrm{ha}^{-1}, \\
& \mathrm{~T}_{2}=1500 \mathrm{~kg} \text { coconut peat } \mathrm{ha}^{-1}, \\
& \mathrm{~T}_{3}=2000 \mathrm{~kg} \text { coconut peat ha } \mathrm{ha}^{-1}, \\
& \mathrm{~T}_{4}=2500 \mathrm{~kg} \text { coconut peat ha } \mathrm{ha}^{-1} .
\end{aligned}
$$

\subsection{Sowing of Seeds}

The seeds were sown on $24^{\text {th }}$ May, 2017. The seeds were sown thoroughly as it was possible to keep uniformity and then the seeds were covered by soils. $0.01 \mathrm{~g}$ seeds $\left(5 \mathrm{Kg} \mathrm{ha}^{-1}\right.$ as recommended by BARI, 2005) were sown in each pot and maximum seeds germinated within 7 days. After germination only five plants were kept in each pot.

\subsection{General Observations}

The pots under experiment were frequently observed to note any change in the crop growth and other characteristics. The crop growth was very luxuriant in some pots and lower in some pots.

\subsection{Harvesting and Preparation of Plant Samples}

After 31 days plant was harvested manually by uprooting the plant carefully from the pot. Then the sampling plants were kept separately. Collected plant 
samples were carefully washed thoroughly with distilled water to remove soil particles and soaked by tissue paper to remove water. After taking fresh weight the plant samples were dried in the oven at $65^{\circ} \mathrm{C}$ temperature for 48 hours until moisture content reached to a minimum level. The dried material of plants per pot from each treatment was recorded.

\subsection{Data Collection of Different Attributes of the Test Crops}

Different growth and yield parameters were recorded and their mean values were calculated from the sample plants during experiment. The number of leaves of five plants of each pot was counted and average value was considered. Shoot length was measured using a measuring scale from root level to the tip of the plant. From each pot five plants were measured and averaged. Root length was measured using a measuring scale from root level to the tip of the longest root at harvest and their average was taken as the root length in $\mathrm{cm}$. Harvest of five plants from each pot, fresh weight of whole plant was taken by an electrical balance and their mean value was calculated as fresh weight expressed in gm plant $^{-1}$.

\subsection{Dry Weight per Plant}

Five plants of each pot were collected and oven dried at $65^{\circ} \mathrm{C}$ for 48 hours, weighed in gm plant ${ }^{-1}$ by an electrical balance and average value was recorded.

\subsection{Moisture Content}

Percent moisture was calculated by using the formula:

$$
\text { Moisture content }(\%)=\frac{W_{f}-W_{o}}{W_{f}} \times 100
$$

where,

$W_{f}=$ Fresh weight of the plant sample,

$W_{o}=$ Oven dry weight of the plant sample.

\subsection{Statistical Analysis}

The collected data were compiled and tabulated in proper form and were subjected to statistical analysis. Standard deviation, Standard error, Analysis of variance (ANOVA) and Duncan Multiple Range Test (DMRT) were done for completely randomized design by using the SAS 6.12 software package [18].

\section{Result and Discussion}

\subsection{Effect of Coconut Peat on the Growth and Yield of Ipomoea aquatica}

The effect of decomposed coconut peat on the growth and yield of water spinach (Ipomoea aquatic) was studied following the pots experiment. The number of leaves per plant, fresh weight per plant, dry weight per plant and percent mois- 
ture contents were measured for the plants treated with $1000 \mathrm{~kg} \mathrm{ha}^{-1}, 1500 \mathrm{~kg}$ $\mathrm{ha}^{-1}, 2000 \mathrm{~kg} \mathrm{ha}^{-1}$ and $2500 \mathrm{~kg} \mathrm{ha}^{-1}$ of coconut peat were compared with plants growth and yield with $0 \mathrm{~kg} \mathrm{ha}^{-1}$ coconut peat which was control for this experiment. The results are presented in Table A2.

\subsection{Number of Leaves per Plant}

The result show that the number of leaves per plant ranged between 8.2 to 10.3 and the maximum number of leaves was counted in $\mathrm{T}_{4}(10.3)$ and the lowest number of leaves was counted in $\mathrm{T}_{0}(8.2)$ presented in the Figure 1 . The control treatment gives minimum number of leaves per plant (8.2) showing statistically significant $(P<0.05)$ variation from $\mathrm{T}_{3}$ and $\mathrm{T}_{4}$ and exception was found in $\mathrm{T}_{1}$ and $\mathrm{T}_{2}$ for the use of less coconut peat.

The increase in leaf number as well as size due to enough nutrition can be explained in terms of possible increase in nutrition absorption capacity of plant as a result of better root development and increase translocation of carbohydrates from source to continuous mineralization of organic manures such as coconut peat. The use of organic manure when properly applied, benefits fruiting in plants like maize and generally enhance size, height and number of leaf's [19]. The maximum number of leaves per plant was obtained in $\mathrm{T}_{4}(2500 \mathrm{~kg}$ coconut peat $\mathrm{ha}^{-1}$ ) was probably due to high amount of coconut peat provided good soil condition for the growth and supplied sufficient plant nutrients.

\subsection{Root Length per Plant}

Coconut peat had an insignificant influence in root length presented in the Figure 2. The longest root $(6.9 \mathrm{~cm})$ was produced by applying $2500 \mathrm{~kg}$ coconut peat $\mathrm{ha}^{-1}\left(\mathrm{~T}_{4}\right)$ and the control treatments $\left(\mathrm{T}_{0}\right)$ produced shortest root length $(5.56$ $\mathrm{cm})$. The result show that the different rates of coconut peat has statically insignificant level of effects on the root length of water spinach and magnitude of difference is at the order of $\mathrm{T}_{4}>\mathrm{T}_{3}>\mathrm{T}_{2}>\mathrm{T}_{1}>\mathrm{T}_{0}$ (Figure 2).

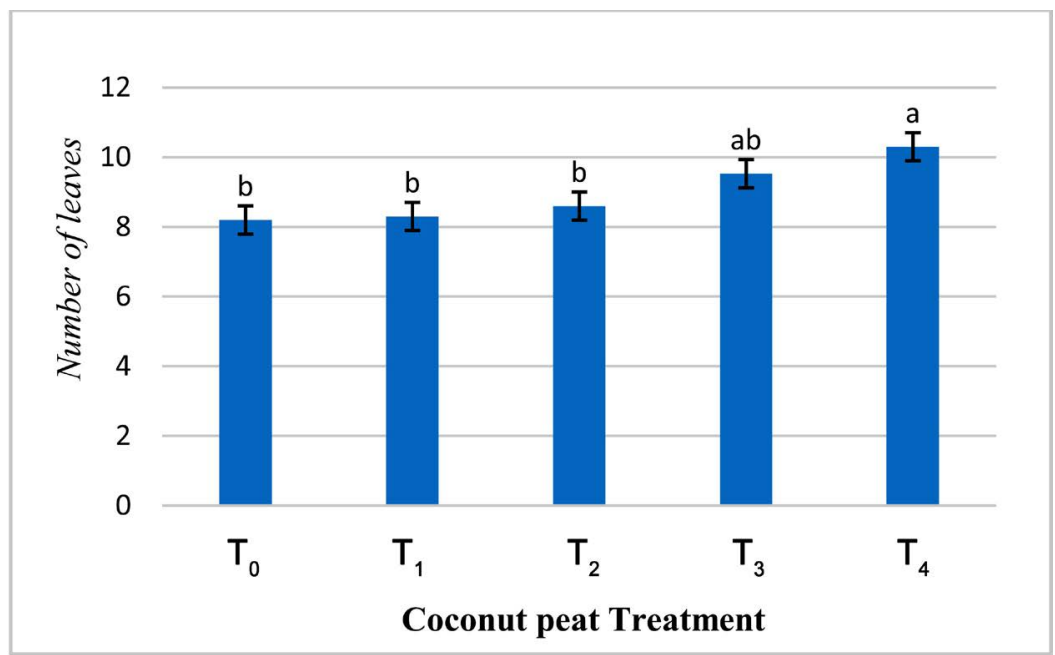

Figure 1. Effect of coconut peat on number of leaves of Ipomoea aquatica. 
According to the results, all treatments of coconut peat showed positives effect on root length of plants from eye observation and data from Table A2. Organic manure improved soil properties, finally, better root growth, better plant growth and biological yield. Development of mineral nutrients in the manure increased root growth, absorption and nutrients, ultimately leading to increase yield [20]. Its soft structure promotes easy root penetration and healthy growth.

\subsection{Shoot Length per Plant}

The result shows that shoot length per plant ranged between $13.26 \mathrm{~cm}$ to $18 \mathrm{~cm}$ in applying different treatments and the maximum shoot length was obtained $\mathrm{T}_{4}$ $(18 \mathrm{~cm})$ and minimum shoot length was in $\mathrm{T}_{0}(13.26 \mathrm{~cm})$ shown in the Figure 3. Results show that shoot length varied statistically insignificantly against control for test crop (Figure 3). According to the results, all treatments of coconut peat showed positive effect on stem height of plants on the basis of data from Table A2.

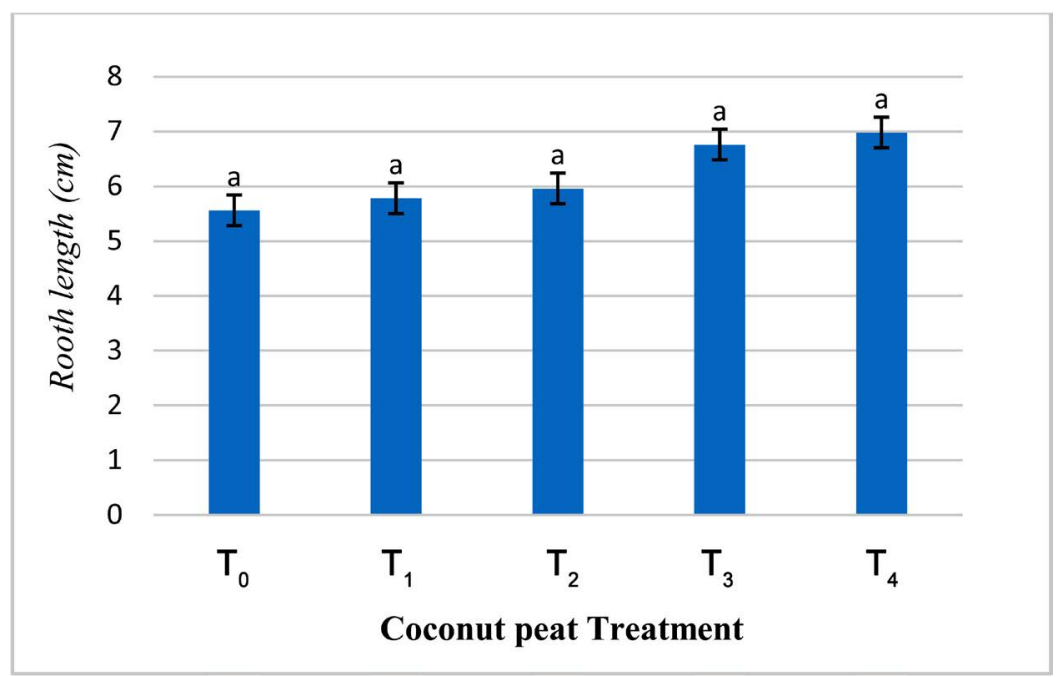

Figure 2. Effect of coconut peat on root length of Ipomoea aquatica.

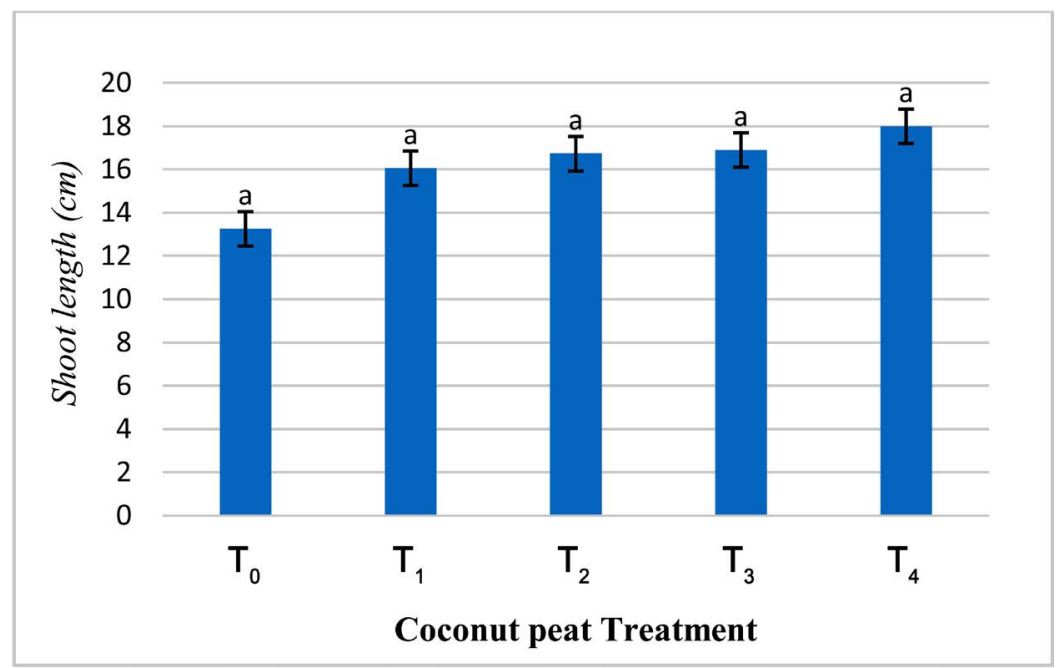

Figure 3. Effect of coconut peat on shoot length of Ipomoea aquatica. 
The positive effect of organic manure like shoot length could be due to the contribution made by manure to fertility status of the soils. Organic manure such as coconut peat play direct role in plant growth as a source of all necessary macro and micro nutrients in available forms during mineralization and improving physical and chemical properties of soils [21]. Babu et al. [22] observed that the plant height was significantly influenced by the incorporation of organic manures. The growth of shoots with increasing manure fertilizer could be due to microorganism activity in soil [23].

\subsection{Fresh Weight per Plant}

The results show that the fresh weight per plant ranged between $1.48 \mathrm{gm}$ to 2.32 gm and maximum fresh weight $2.32 \mathrm{gm}$ per plant was measured in $2500 \mathrm{~kg}$ coco peat $\mathrm{ha}^{-1}$ treated plants $\left(\mathrm{T}_{4}\right)$ and the lowest was measured $1.48 \mathrm{gm}$ in control plants $\left(\mathrm{T}_{0}\right)$ on the basis of data from Table A2. Result shows that fresh weight per plant was found statistically $(P<0.05)$ significant variation against control for test crop (Figure 4). The result shows that the different treatments also have significant level on the effect on the receiving plants and magnitude of the difference is at the order of $T_{4}>T_{3}>T_{2}>T_{1}>T_{0}$ (Figure 4). Four different rates of coconut peat gave positive effect on fresh weight of plant in the present study. Role of organic manure in increasing yield of water spinach was attributed to supply of all essential nutrients due to continuous mineralization of organic manure. Manure acts as nutrient reservoir and upon decomposition produces organic acids, thereby absorbed ions are released slowly during entire growth period leading to higher yield components. Bardar et al. [24] reported the beneficial effects of organic manure on growth of cowpea plants. The increase in fresh weight has also been reported by Sarwar et al. [25] and Manivannan et al. [26].

\subsection{Dry Weight per Plant}

The results show that the dry weight per plant ranged between $0.2 \mathrm{gm}$ to $0.31 \mathrm{gm}$

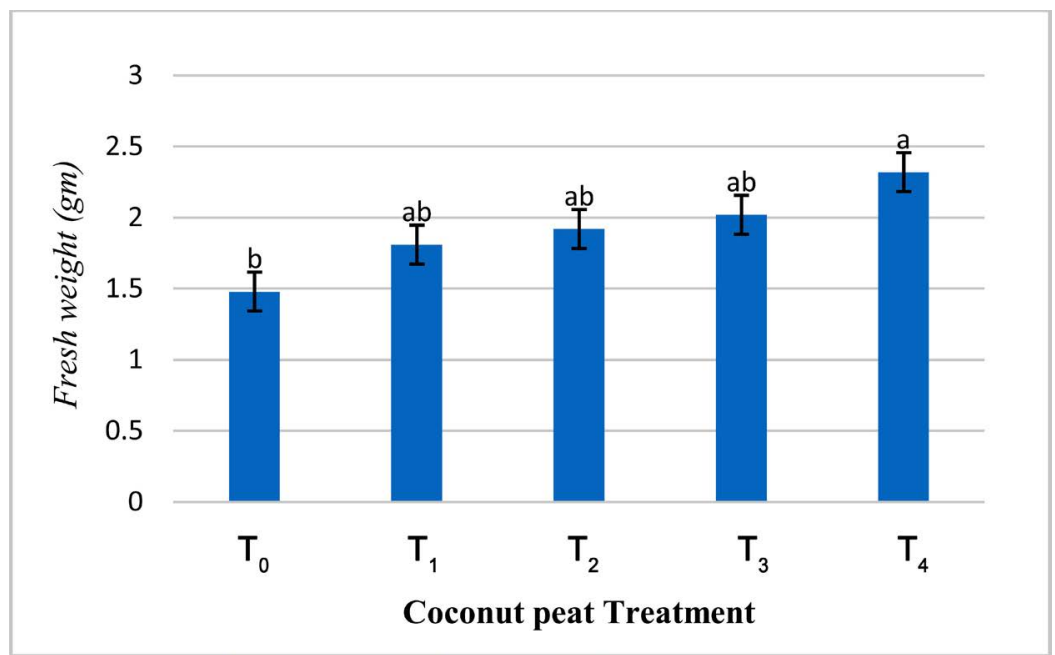

Figure 4. Effect of coconut peat on fresh weight of Ipomoea aquatica. 
and the maximum dry weight $0.31 \mathrm{gm}$ was obtained for applying $2500 \mathrm{~kg}$ coconut peat plant ${ }^{-1}\left(\mathrm{~T}_{4}\right)$ and the minimum was measured $0.31 \mathrm{gm}$ from control plats $\left(\mathrm{T}_{0}\right)$ on the basis of data from Table A2. Result shows that dry weight per plant varied statistically $(P<0.05)$ significantly against control for test crops (Figure $5)$. The results reveal that the application rate has a significant impact on the fresh weight of the plants. According to the results, all treatments of coconut peat showed positive effect on dry weight of plants. It is possible that increased application rate could be increased the fresh weight per plan. Adding manure in soil improve soil physical and biological conditions and create a more favorable environment for root growth and nutrients availability, increased plant growth and dry matter [20] [27].

\subsection{Moisture Content per Plant}

The results show that the moisture content (\%) ranged between $85 \%$ to $86.57 \%$ and the maximum moisture content was $86.57 \%$ obtained for applying $0 \mathrm{Kg}$ coconut peat $\mathrm{ha}^{-1}\left(\mathrm{~T}_{0}\right)$ and the lowest was measured $85 \%$ for applying $1000 \mathrm{~kg}$ coconut peat ha $\mathrm{h}^{-1}$ in treatment $\left(\mathrm{T}_{1}\right)$ on the basis of data from Table A2. The results show that the different application rate has insignificant level of effect on receiving plants and magnitude of the difference is at the order of $\mathrm{T}_{4}>\mathrm{T}_{3}>\mathrm{T}_{2}>$ $\mathrm{T}_{0}>\mathrm{T}_{1}$ (Figure 6) on moisture content (\%). However, the difference of moisture content (\%) among treatments was statistically insignificant in most of the cases (Figure 6). The causes of variation may due to the nutrient availability of the plants.

\section{Conclusion}

The study was carried out to assess the effect of coconut peat on growth and yield response of Ipomoea aquatica for Pirojpur soil series. The target of application of different rates of coconut peat $\left(1000 \mathrm{~kg} \cdot \mathrm{ha}^{-1}, 1500 \mathrm{~kg} \cdot \mathrm{ha}^{-1}, 2000 \mathrm{~kg} \cdot \mathrm{ha}^{-1}\right.$ and $2500 \mathrm{~kg} \cdot \mathrm{ha}^{-1}$ ) was to obtain reasonable growth and yield to optimum levels.

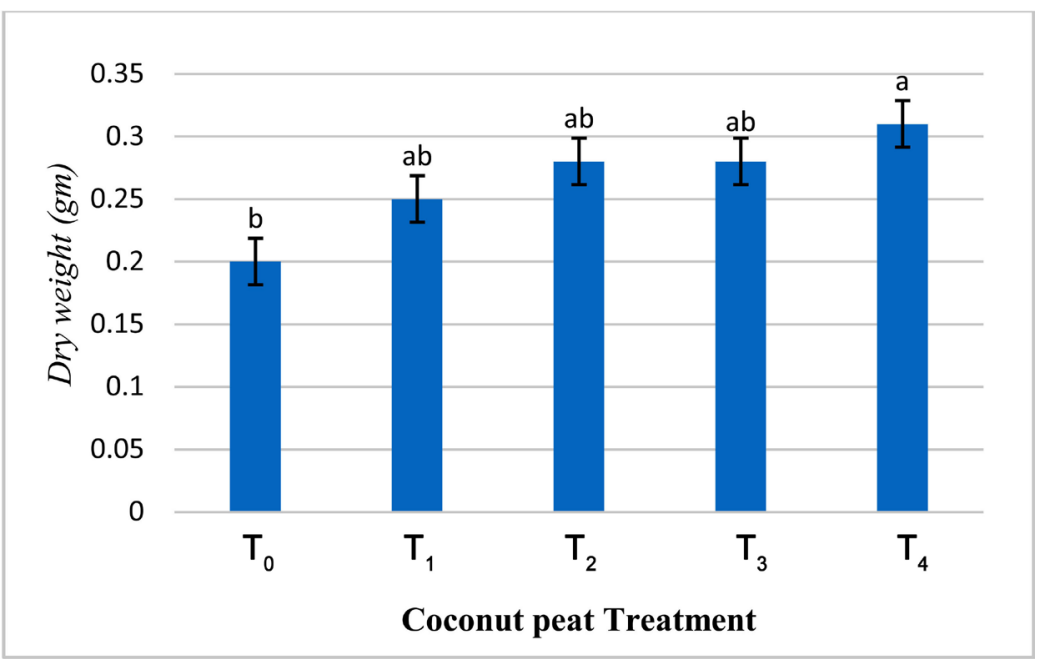

Figure 5. Effect of coconut peat on dry weight of Ipomoea aquatica. 


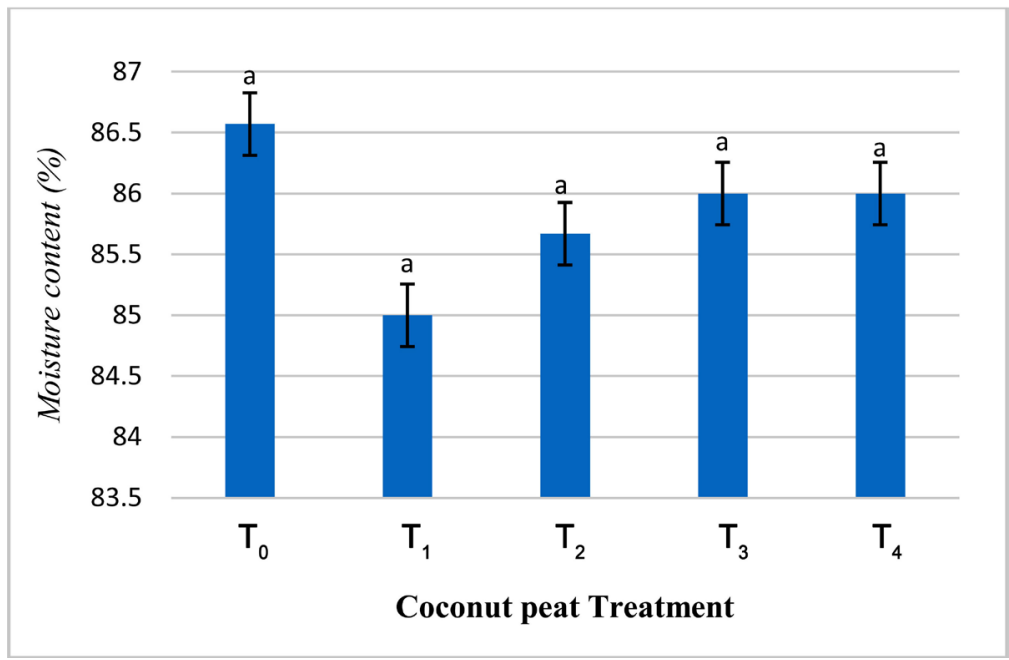

Figure 6. Effect of coconut peat on moisture content of Ipomoea aquatica.

The study has revealed that coconut peat has significantly $(\mathrm{P}<0.05)$ influence on the growth of Ipomoea aquatica. On the basis of number of leaves per plant, fresh weight per plant and dry weight per plant, it obviously mentioned that the real growth of plant is mainly depends on dry weight per plant which is significantly $(\mathrm{P}<0.05)$ increased by the application of coconut peat. On the contrary the root length per plant and shoot length per plant are insignificantly varied compared to control treatment but from the eye observation and data presented in Appendix confirm increasing trend for the application of coconut peat. Among the five treatments applied $\mathrm{T}_{4}$ treatment $\left(2500 \mathrm{~kg}\right.$ coconut peat ha $\left.{ }^{-1}\right)$ has shown highest response to plant growth. The sequence of response was in the order $\mathrm{T}_{4}>\mathrm{T}_{3}>\mathrm{T}_{2}>\mathrm{T}_{1}>\mathrm{T}_{0}$. High rates of coconut peat increase the growth of Ipomoea aquatica. Treatments gave significantly $(\mathrm{P}<0.05)$ difference in plant growth from the control.

\section{Acknowledgements}

All praise is to supreme being, creator and ruler of the universe whose mercy enables the authors to finish this research work. We thank Professor Afroza Begum and Professor Dr. Shaikh Motasim Billah for their sincere supervision, valuable instruction for completion of this research work. We also thank an anonymous reviewer for their constructive criticism of the script and their valuable suggestions. This paper is dedicated to Monia Dilshad Era who collected soil and coconut peat sample with her cordial cooperation.

\section{Conflicts of Interest}

The authors declare no conflicts of interest regarding the publication of this paper.

\section{References}

[1] Ali, M.M., Shaheed, S.M. and Kubota, D. (1997) Soil Degradation during the Period 
1967-1995 in Bangladesh. Selected Chemical Characters. Soil Science and Plant Nutrition, 43, 879-890. https://doi.org/10.1080/00380768.1997.10414654

[2] BARC (2012) Fertilization Recommendation Guide. Bangladesh Agricultural Research Council. Farm Gate, Dhaka.

[3] Ali, M.R., Costa, D.J., Abedi, M.J., Sayed, M.A. and Basak, N.C. (2009) Effect of Fertilizer and Variety on the Yield of Sweet Potato. Bangladesh Journal of Agricultural Research, 34, 473-480. https://doi.org/10.3329/bjar.v34i3.3974

[4] Pryce, S. (1990) Alternatives to Peat. Properties of Horticulture, 5, 101-106.

[5] Bragg (1991) Peat and Its Alternatives. Horticultural Development Council, Petersfield.

[6] Batra, S.K. (1985) Other Long Vegetable Fibers. Handbook of Fiber Science and Technology \#4.

[7] Savithri, P., Murugappan, V. and Nagarajan, R. (1993) Possibility of Economizing K Fertilization by Composted Coir Peat Application. Fertilizer News, 38, 39-40.

[8] Handreck, K.A. (1993) Properties of Coir Dust, and Its Use in the Formulation of Soilless Potting Media. Community of Soil and Plant Analysis, 14, 349-363. https://doi.org/10.1080/00103629309368804

[9] Savithri, P. and Khan, H.H. (1993) Characteristics of Coconut Coir Peat and Its Utilization in Agriculture. Journal of Plant Crop, 22, 1-18.

[10] Abad, M. (1995). La fibra de coco, unnuevo substrattohorticola para el cultivo sin suelo. VI Congresode la Sociedad Espanolade Ciencias Horticolas, Barcelona.

[11] Altuhaish, A., Hamim and Tjahjoleksono, A. (2014) Biofertilizer Effects in Combination with Different Drying System and Storage Period on Growth and Production of Tomato Plant under Field Conditions. Emirates Journel of Food and Agriculture, 26, 716-722.

[12] Adesemoye, A.O., Torbert, H.A. and Kloepper, J.W. (2009) Plant Growth-Promoting Rhizobacteria Allow Reduced Application Rates of Chrmical Fertilizer. Microbial Ecology, 58, 921-920. https://doi.org/10.1007/s00248-009-9531-y

[13] Higa, T. (1991) Effective Microorganism: A Biotechnology for Mankind. The 2nd International Conference on Kyusei Nature Farming at the University of Soa Paul.

[14] SRDI (1989) Vumi o mrittika Sompod Babohar Nirdeshika Guideline. Soil Resource and Development Institute, Dhaka, $40 \mathrm{p}$.

[15] Rahman, M.R. (2005) Soils of Bangladesh. Darpon Publications, Dhaka.

[16] BARI (2005) Recommendation of Seed Sowing for Different Leafy Vegetables. Bangladesh Agricultural Research Institute, Joydevpur.

[17] Gomez, K.A. and Gomez, A.A. (1984) Statistical Procedure for Agricultural Research. 2nd Edition, International Rice Research Institution, Willey International Science Publication, 28-192.

[18] SAS (1988) SAS/STAT User's Guide, No. 1, ANOVA, Version 6. 4th Edition, Statistical Analysis System Institute, Cary.

[19] Baskaran, M. and Saravanan, A. (1997) Effect of Coir Pith Based Potting Mix and Methods of Fertilizer Application on Tomato. Madras Agricultural Journal, 84, 476-480.

[20] Valiki, S.R.H. and Ghanbari, S. (2015) Comparative Examination of the Effect of Manure and Chemical Fertilizer on Yield and Yield Components of Rosemary ( $R o-$ semarinus officinalis L.). Vegetables Science, 6, 29-37.

[21] Chaterjee, B., Ghanti, P., Thapa, U. and Tripathy, P. (2005) Effect of Organic Nutri- 
tion in Sprouting Broccoli (Brassica oleraceae var.) Vegetable Science, 33, 51-54.

[22] Babu, S., Marimuthu, R., Manivanna, V. and Rameshkumar, S. (2001) Effect of Organic and Inorganic Fertilizer on Growth and Yield of Rice. Agricultural Science Digest, 21, 232-234.

[23] Gryndler, M., Sudova, R. and Rydlova, J. (2008) Cultivation of High Biomass Crops on Mine Spoil Banks: Can Microbial Inoculation Compensate for High Doses of Organic Matter. Bioresource Technology, 99, 6391-6399. https://doi.org/10.1016/j.biortech.2007.11.059

[24] Bardar, R., Aslam, I., Ibrahim, S. and Shabbir, S. (2015) Comparative Effect of Composts with Microbial Inoculants on the Growth of Vigna Radiate. International Journal of Pharmaceutical and Biological Science, 3, 100-105.

[25] Sarwar, G., Schmeisky, H., Hussain, N., Muhammad, S., Ibrahim, M. and Safdar, E. (2008) Improvement of Soil Physical and Chemical Properties with Compost Application in Rice-Wheat Cropping System. Pakistan Journal of Botany, 40, 275-282.

[26] Manivannan, S., Balamurugan, M., Parthasarathi, K., Gunasekaran, G. and Ranganathan, L.S. (2009) Effect of Vermicompost on Soil Fertility and Crop Productivity-beans (Phaseolus vulgaris). Journal of Environmental Biology, 30, 275-281.

[27] Kalpan, M., Kocabas, I., Sonmez, I. and Kalkan, H. (2009) The Effect of Different Organic Manure Application on the Dry Weight and Essential Oil Quantity of Sage (Salvia fruiticosa Mill). Acta Horticulture, 826, 47-152. 


\section{Appendix}

Table A1. General information of the experimental soil.

\begin{tabular}{cc}
\hline & General information \\
\hline Location & Khulna district, Bangladesh \\
GPS: $22^{\circ} 48.302 \mathrm{~N}$ and $89^{\circ} 31.962 \mathrm{E}$ \\
AEZ & Ganges tidal floodplain, (AEZ-13) \\
EC & $8.10 \mathrm{dS} \mathrm{m}^{-1}$ \\
$\mathrm{pH}$ & 8.25 \\
SAR & 2.01 \\
CEC & 20.8 Cmolc $(+) \mathrm{kg}^{-1}$ \\
$\% \mathrm{OC}$ & $0.78 \%$ \\
$\% \mathrm{OM}$ & $1.35 \%$ \\
$\% \mathrm{~N}$ & $0.14 \%$ \\
C:N & 5.6 \\
Calcareousness & Calcareous \\
Textural class & Silty clay \\
\hline
\end{tabular}

Table A2. Growth and yield of ipomoea aquatica and change of yield due to coconut peat treatment.

\begin{tabular}{ccccccc}
\hline Treatment & $\begin{array}{c}\text { No of leaves } \\
\text { per plant }\end{array}$ & $\begin{array}{c}\text { Root length per } \\
\text { plant }(\mathrm{cm})\end{array}$ & $\begin{array}{c}\text { Shoot length per plant } \\
(\mathrm{cm})\end{array}$ & $\begin{array}{c}\text { Fresh weight per plant } \\
(\mathrm{gm})\end{array}$ & $\begin{array}{c}\text { Dry weight per plant (gm) } \\
\text { Moisture content } \\
(\%)\end{array}$ \\
\hline $\mathrm{T}_{0}$ & $8.2 \mathrm{~b}$ & $5.56 \mathrm{a}$ & $13.26 \mathrm{a}$ & $1.48 \mathrm{~b}$ & $0.2 \mathrm{~b}$ & $86.57 \mathrm{a}$ \\
$\mathrm{T}_{1}$ & $8.3 \mathrm{~b}$ & $5.78 \mathrm{a}$ & $16.06 \mathrm{a}$ & $1.81 \mathrm{ab}$ & $0.25 \mathrm{ab}$ & $8.28 \mathrm{ab}$ \\
$\mathrm{T}_{2}$ & $8.6 \mathrm{~b}$ & $5.96 \mathrm{a}$ & $16.73 \mathrm{a}$ & $1.92 \mathrm{ab}$ & $8.28 \mathrm{ab}$ & $86.67 \mathrm{a}$ \\
$\mathrm{T}_{3}$ & $9.53 \mathrm{ab}$ & $6.76 \mathrm{a}$ & $16.9 \mathrm{a}$ & $2.02 \mathrm{ab}$ & $0.31 \mathrm{a}$ & $86 \mathrm{a}$ \\
$\mathrm{T}_{4}$ & $10.3 \mathrm{a}$ & $6.98 \mathrm{a}$ & $18 \mathrm{a}$ & $2.32 \mathrm{a}$ & $86 \mathrm{a}$ \\
\hline
\end{tabular}

Means followed by different letters in each column are significantly different $(\mathrm{P}<0.05)$ according to Duncan Multiple Range Test. 